特 菒 6 *

急性出血性胃病変を含む急性胃潰瘍の成因と対策

\author{
横浜市立大学第 2 外科 \\ 杉山貢山中研 \\ 渡辺桂一土屋周二

\section{PATHOPHSIOLOGY AND TREATMENT OF ACUTE GASTRIC MUCOSAL LESION AND ACUTE GASTRIC ULCER}

\section{Mitsugi SUGIYAMA, M.D.} \\ Second Department of Surgery, Yokohama City University School of Medicine
}

\begin{abstract}
索引用語 : acute gastric mucosal lesion, microcirculation, hexosaminidase, ${ }^{86} \mathrm{Sr}$-microsphere, Curling ulcer
\end{abstract}

\section{I. はじめに}

近年, 急性上部消化管出血の主な原因疾患として, 急 性出血性胃病変を含む急性胃潰瘍に対して関心が向けら れ，数多くの研究がみられる.しかしその成因はいまだ 明確ではなく，したがって治療も一定せず，また治療成 績も甚だ不良である。一般に急性出血性胃病変, (acute hemorrhagic gastric erosion) および急性胃病変 (acute gastric mucosal lesiou, AGML) と呼ばれる変化は中权 神経系の障害 (脳卒中, 脳外傷など) や重度熱傷, 敗血 症, ショック, 呼吸不全, 手術, 骨折, 心䇨硬塞, 精神 的ストレスなどのストレス状態下, またアルコール摄取, レセルピン, アスピリン, 副腎皮質ホルモン剤などの胃 粘膜の障害を起こす薬剤等により惹起される. 今回, こ れらの急性胃病变の病態を実験的に熱傷といらストレス 負荷により再現し，以下の 3 項目について検索した。

(1) ストレス負荷後の消化管における微小循環の経時 的变化を形体学的に観察する.

変化を測定する.

(2)，胃・十二指腸の壁内における血流量の変化を測定 する.

(3)，消化管壁，とく粘膜の抵抗性 (防御機構) を粘 膜内糖蛋白の消長より観察する。

* 第13回日消外総会シンポ 1

胃溃湯（急性ならびに慢性）の成因と外科治療
また以上の検索より，本症の病態面よりみた対策を臨 休例を含めて，文献的考察を加觉報告する。

\section{II. 実験的急性男病変の病態}

われわれは, 日常診療上, 熱傷後飞発生する上部消化 管出血 (Curling's ulcer ${ }^{1)}$ ) によく遭遇する。これらの 症例に対し最近では，まずその病変を把握るすため, 緊 急胃内視鏡検查を施行し，広範团にわたる粘膜面からの 出血とびらん,などの急性出血性胃病変 (AGML) 像を 観察しその治療方針が決定される．そこで今回，実験的 に Wister 系ラットを用い，熱傷後の急性胃病変の再現 を試み，本症に和ける病態を検索し，またこれに対する 2 ・ 3 の対策についても検討した.

1)，熱傷による実験的急性胃病変の作成

Wister 系雄ラット（250〜400g）を用い，24時間絶食 後 Walker ${ }^{2)}$ らの方法に準し，熱傷をラット背部に作成 した.すなわちアクリル樹脂により背部のみを露出させ る器具を作成し, これにェーテル麻醉下にてラットを固 定し, $90 \sim 100^{\circ} \mathrm{C}$ の熱湯中に10秒間浸した. この操作に より体表面積（体重2/3×10）の25 30\%に full thickness burn が形成された（図 1). 熱傷後直に, 生食水 $(100 \mathrm{ml} / \mathrm{kg})$ を腹空内に注入乙蘇生を行い $1,2,4$, $6,24,48,72$ 時間群に分け各項目について検索した. 熱傷形成後, 経時的に胃・十二指腸部を観察すると, 1 時間後では 21 例中15例 $(71.4 \%)$ の胃に明らかな3ケ月 以上の出血点がみられ, 粘膜は著明に発赤し, 浮腫状で 
図 1 熱傷作成に用いたアクリル樹脂の器具とラッ ト 30\%熱傷 (full thickness burn)

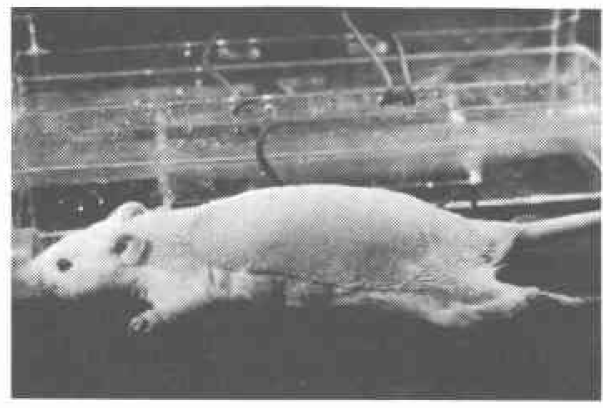

図2 熱傷後 2 時間の胃（黑い斑点が出血部位）

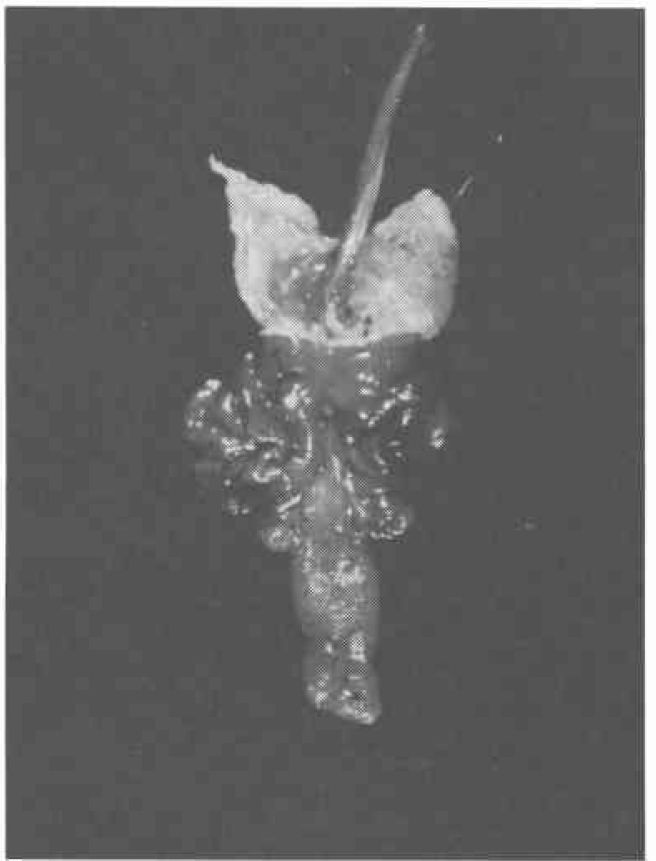

あった． 2 時間を経過すると28例中 27 例 $(96.4 \%)$ 飞性 出血性胃病変が観察された（図 2).また 4,6 時間と時 間の経過と共に出血点の数と浮腫状の変化は著明となっ た.しかし48時間後では，17例中10例 $(58.8 \%)$ 亿出血点 も認められるが，これより発赤と浮腫の方が目立った。 さらに72時間後では出血点の認められるのは13例中 6 例 (46.1\%)のみとなり, 明らかに減少してくることが観 察された。

2), 胃壁内の微細血管構築（微小循環）の経時的变化 熱傷後 $1 ， 2 ， 4$ 時間群に分け，比較的早期にお晾る
胃壁内微細血管構築の变化を対照群（非熱傷, 絶食）と 比較した．各群を決められた時間にェーテル麻醉下で開 胸開腹し, 胸部大動脈にシリコンカテーテルを挿入し， ヘパリン生食水を $100 \mathrm{~cm}$ 水柱压で潅流させる（3〜 分間). その後同部より色素 (indian black) $120 \mathrm{~cm}$ 水 柱压で注入し，5～7ml 注入後胃・十二指腸壁の漿膜面 が着色したところで，直に胃・十二指腸を摘出し，あら かじめ用意しておいたドライアイス，ィチルアルコール $\left(-78^{\circ} \mathrm{C}\right)$ 中で瞬間凍結固定した ${ }^{3)}$ これを50〜 $100 \mu$ の 厚さに切り出し，サリチル酸メチルにより結合織を脱 色させて透明標本を作成し 顕微鏡下で 観察した。一般 に消化管の 微小循環系 (microcirculatory system) は, 動脈系では細動脈 (arteriole) $\rightarrow$ meta arteriole $\rightarrow$ true capillaries $\rightarrow$ 固有毛細管 (capillaries prop.) $\rightarrow$ 静脈側一 と移行する゙が，今回はことに急性胃病変の発生過程を 観察するために主として粘膜表層の変化を観察した。対 照群 (非熱傷) では粘膜表層の先端まで色素の粒子が観 察され，しか子その像は規則正しい構造を呈していた。

（図 3-a）熱傷後 1 時間経過すると, 胃粘膜の表層面で は色素粒子が観察されず，この部位では血流が閉ざされ ているものと思われた。な拉，血流の保たれている粘膜 中層(いわゆる濃染帯)への色素粒子の集合状況は一様で はなく，特に出血点の部位ではこの濃染帯から粘膜下層 の幅は縮小し，粘膜表層の脱落もみられた（図 3-b).熱 傷後 1 時間目になると，胃全体に血流障害のため色素粒 子が到達しない粘膜表層の幅はさらに拡がり，反面，血 流が保たされている濃染帯（粘膜中層）の濃淡が一様で なくなりしかも粘膜下層までの幅はさらに短縮した。 この時期になると，一部粘膜上層は所々で壊死脱落し肉 眼的にもほぼ100\%に点状出血が 観察された. 一方，粘 膜下層に沶いては，払張した血管が豊富となりしかも所 々に怒張した静脈，む観察された（図 3-c).ささらに 4 時 間経過すると，粘膜上㬝には広範に壊死脱落がみられ た. 血流の保たれている濃染帯の濃淡は様々で，またそ の幅は一様でなはく，しかも，この帯が欠損する部位も みられた（図 3-d). この時期に招いて，胃の粘膜面から 特殊レンズを使用し，生体観察)をすると，対照群に比 べて毛細管の血流は障害され， sludging 現象がみられ た。 また集合細静脈の樹板状拡張がみられ，出血点は所 々で虑合しながら拡がりその中心では粘膜が脱落し，ま たその周辺では浮腫状の変化とびらんが観察された（図 4 ). 以上の形体学的観察より, 熱塲後 2 4 時間までの 早い時期に执いては，時間の経過とともに胃粘膜の表層 
図 3-a: ×60, 図 3-b: ×40, 図 3-c: $\times 40$, 図 3-d : $\times 60$

ラット胃の色素注入後の透明標本〔熱傷後の経時 的変化]

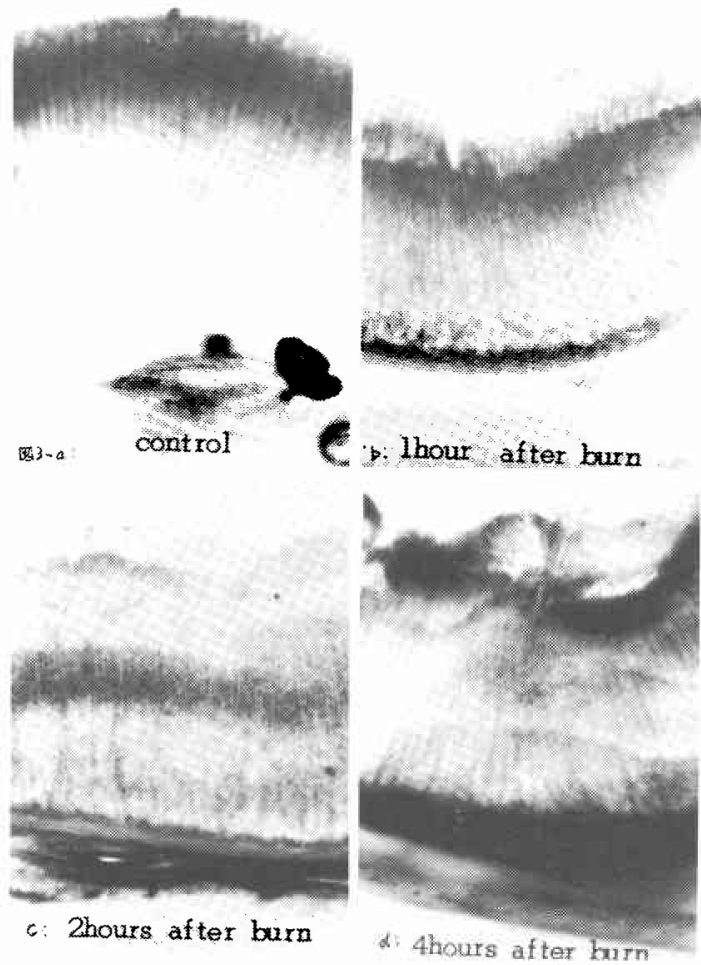

図 4 熱智後 4 時間の生体㘥察 $\times 6$ （中心の不在 の黒色部は癒合した出血点, 周りの白色部は一部 びらんと浮腫を示す)

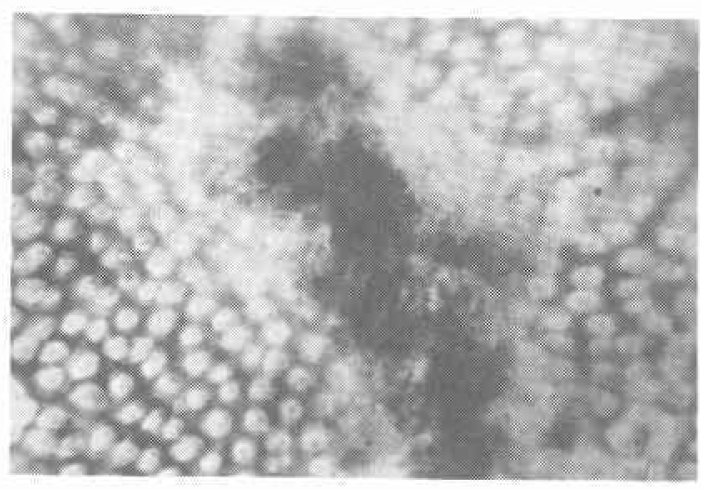

から深層へと進行する微小循環の障害, それにともなら 組織の壊死脱落と出血により急性胃病変が完成するもの と思われた。
3), 胃壁内の血流量の経時的変化

実験的熱傷によるストレス負荷後，1〜6時間といら 早期においては胃壁内の微小循環障害が認められ, 殊に この変化は粘膜上層に执いて顕著であり, 肉眼的にも2

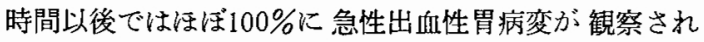
た.この胃壁内での微小循環障害, すなわちストレス負 荷が胃壁内の血流量に及ぼす影響を数値的に検索した。 実験的急性胃病変の作成は2)，の項目と同様であり，熱 傷後の経過時間は $1 ， 2 ， 4$ 時間までとした．血流量の 測定には Rudolph ${ }^{6)}$ らが開発した, ${ }^{85} \mathrm{Sr}$. microsphere 法 を用いた。すなわち本法の原理は indicator dilution 法 の一種であり，その indicator には ${ }^{85} \mathrm{Sr}$. で標識化さ れた $25 \pm 5 \mu \mathrm{m}$ (ISD) の大きさで $1 \mathrm{gm}$ 中に $2.57 \mathrm{mCi}$ の specific activity を有した, 生物学的に不活性な炭素球 を使用した。この標識 microsphere 左心房より注入し， 拍出された全量 (拍出量) は各臓器へ血流量に比例して 分布するといら考兵のもとに，組織血流量を心拍出量に 対する組織分布率より求める方法である。しかし対象が ラットという小動物であめるため左頝動脈から左心室及 び一部大動脈に注入した量 (注入量)を cardiac output として，これに対する各部位への分布を算定した。すな わち各部の\%cardiac output を比較した。なお,ラット の臓器 (胃・十二指腸) は小さく薄く筋層, 粘膜層の分 離が困難なため全層を用いて, auto $\gamma$ counter にて測定 した．対照群（非熱傷群）のラット前胃での\%cardiac

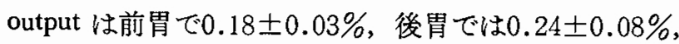
十二指腸では0.33士0.10\%であった。熱傷後の胃壁内の 血流量の変化は時間の経過と共に著明に減少した。すな わち 1 時間後では各々， $0.07 \pm 0.02 \% ， 0.14 \pm 0.06 \%$ ， $0.20 \pm 0.08 \%$ であり，さらに 4 時間後では各々，0.04士 $0.01 \% ， 0.10 \pm 0.03 \% ， 0.09 \pm 0.01 \%$ 低下した（図 5-a).この結果はあくまでも胃・十二指腸壁の変化であ るが, 2.2)の項で前述した形態学的变化（粘膜内微小循 環障害）からみても，また虚血時の胃血流減少は粘膜層 に著明であるといら大橋》らの報告から推察しても，本 病態下の胃壁全層を含めての血流减少は, 主として粘膜 内血流量減少によるものと考圥られる。

4)，消化管壁，とくに粘膜内糖蛋白の消長

熱傷後の急性胃病変発生過程に打いて，胃壁の低抗性 (防御機構) に変化が生じるかどらか，またストレス負 荷後に観察された粘膜面での虚血性変化が粘膜内の糖蛋 白量の消長に影響すどるからかを検索した．胃壁の防御 因子については, mucous barrier の構成成分 hexosamine 
図 5-a 30\%熱傷後, 胃壁内血流量の変化 $\left({ }^{85} \mathrm{Sr}\right.$ microsphere 法ラット)

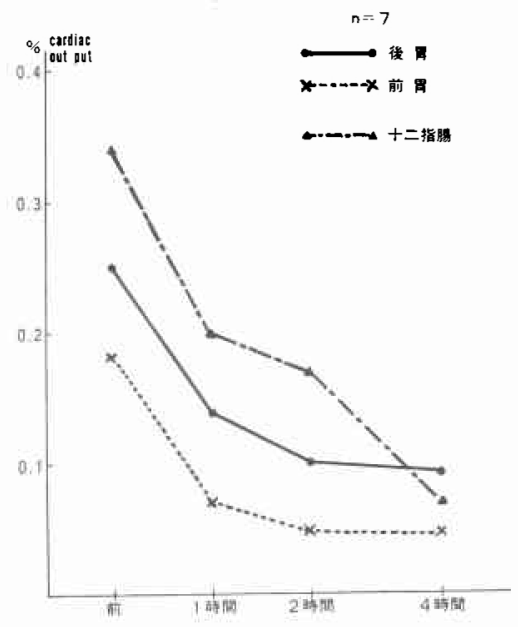

図 5-b 30\%熱傷後, 胃壁内血流量の変化 $\left({ }^{85} \mathrm{Sr}\right.$ microsphere 法ラット)

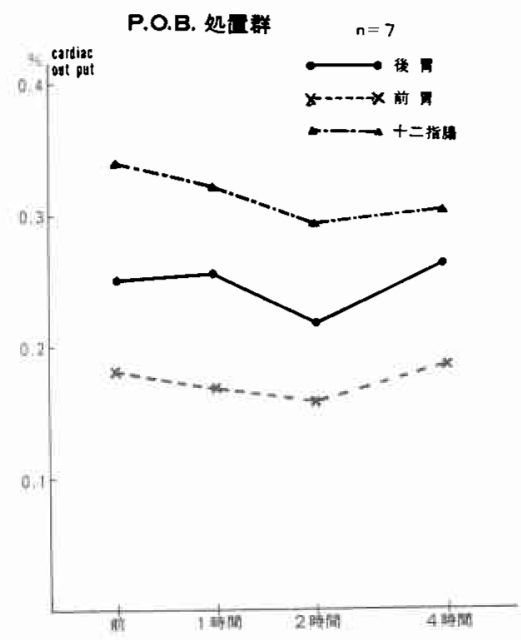

の分解酵素である, hexosaminidase の活性を 胃壁（組 織) 内で測定することにより検索した．測定法 ${ }^{8)}$ は，4methyl-umbelliferone-glucosaminide (-galactosaminide) を基質とする蛍光法により， N-acetyl- $\beta$-D-glucsosaminidase (-galactosaminidase) 活性を測定した。測定組織は ラット胃・十二指腸壁の全層をホモジェナイズしたも のを用い, 活性単位 (hexosaminidase activity) は units/ mg, wet. wt. により判定した。熱傷ストレス負荷前, 後胃 (胃腺部) では glucosaminidase 活性が60単位犬゙っ たものが，負荷後15分以内に一時的に上昇をみ，以後，
図 6-a hexosaminidase 活性（後胃）(30\% burn k よる経時的変化) $n=10$

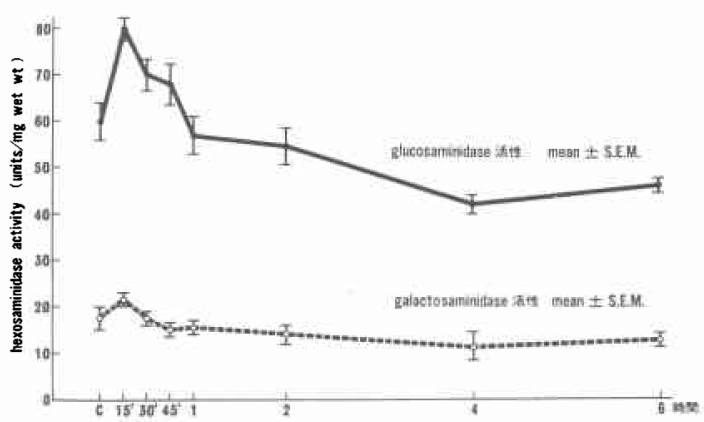

困 6-b hexosaminidase 活性（後胃）P.O.B. cimetidine 処置群 (30\% burn 达る経時的变化) $\mathrm{n}=5$

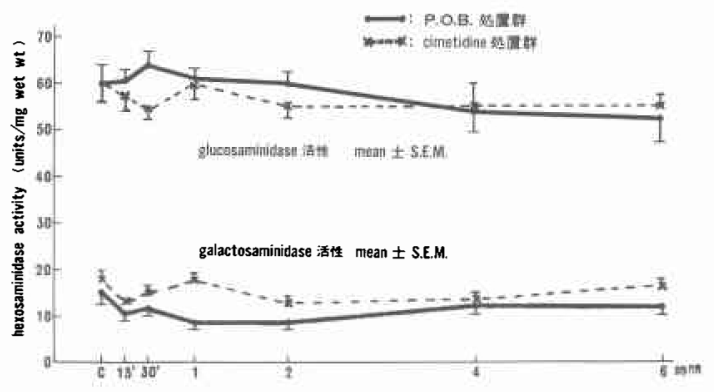

徐々に活性値が低下し，4 時間後では39単位（熱傷前の 65\%）と有意に低下をみた。一方, galactosaminidase 活 性は全体的にその変化率は小さく,18単位から10単位へ と低下したがその pattern は glucosaminidase 活性の変 化と近似していた（図6-a). 著者ら ${ }^{8)}$ はすでにイヌで, 胃への血流障害 (虚血) により, 胃粘膜内酵素活性（主 に glucosaminidase 活性) が低下することを報告してき たが,この結果とを考学合わせると，本実験に扣いてる 熱傷により早期に発生する胃壁内（粘膜内）虚血性変化 が粘膜の抵抗減弱を若起させたるのと思われる。

\section{III. 急性胃病変を含む急性霄洪泬の対策}

1), 実験的急性胃病変の予防

実験的急性胃病変の対策を予防面より検索するため, phenoxybenzamine (POB) $0.2 \mathrm{mg} / \mathrm{kg}, \mathrm{H} 2$-receptor antagonist (cimetidine) $0.1 \mathrm{mg} / \mathrm{kg}$ の影響を観察した. POB を熱傷 3 時間前より, 熱傷後 4 時間まで30分毎に連続筋 注投与した。また cimetidine を24時間前より（前： 6 回, 後: 30分毎) 経口投与した. 両群では熱傷後 4 時間 を経ても胃病変は軽度であり, 特に POB と cimetidine 併用例では明らかに非投与群に比べて粘膜病変は軽く, 
出血点はほとんど認められなかった. また, $\mathrm{POB}$ 投与群 に扣ける熱傷後の胃壁内血流量の変化を2,3)の項と同様 の方法で ${ }^{85}$ Sr.-microsphere 法により検索したが, 熱傷単 独例比比べてその変化は明らかに軽く，壁内血流がよく 保たれているものと思われた.すなわち前胃では，熱傷

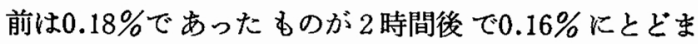
り，4時間後には回復が認められた. 後胃でも各々0.24 \%から0.23\%，十二指腸 では $3.3 \%$ か $0.30 \%$ とその変 化は軽く，4時間後では明らかに回復傾向が認められ た.なお， POB 投与のみによる血行動態の变化は明ら かでないが，それ熱傷といらストレス負荷した場合に は明らかに胃壁内の血流, ことに粘膜内の微小循環が保 たれるものと考光られる（図 5-b).

次に各種薬剤の予防効果を防御因子の面からみるため に, 熱傷後の胃壁内の hexosaminidase 活性の推移を検 索した。無処置群では 4 時間目で glucosaminidase 活性 の低下（熱傷前の65\%）が顕著であったのに対して, POB 群では熱傷前の86\%の醳素活性が保たれていた。 また cimetidine の処置群でも 4 時間值で熱傷前の $81 \%$

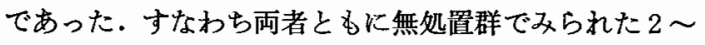
4 時間後の著明な醉素活性の低下を予防することができ た(図 6-b).

2), 実験的急性胃病変加潰瘍化への因子と迷切： 熱傷による実験的急性胃病変は48～72時間と日時の経過 とともに回復がみられ出血点の数も減少していた。また 5 日を経ると組織学的には一部再生上皮が観察される. そこで著者らはこの急性胃病変が急性潰瘍に進行して行 く因子として,特に胃酸分泌の元進について注目した, 熱 傷前 1 時間と熱傷後は 3 時間毎にヒスチミン $2 \mathrm{mg} / \mathrm{kg}$ を 皮下に連続投与した。熱傷単独群では48〜 72時間後に治 癋傾向のある,びらんないし点状出血が観察されたのに 対して,ヒスチミン投与群では明らかに出血を伴った U1 III Nの深い急性胃潰瘍が認められた（潰演部の色素 注入後瞬間凍結透明標本 $\times 40$ ) (図 7).一方, ヒスチミ ン投与による酸分泌を抑えるために術後 3 力月を経過し た迷切群（全迷切兼幽門形成）に熱傷を与え，ヒスチミ ン連続投与を行ったところ, 熱傷単独群で見られた様な 浅いびらんにとどまり深い急性潰瑒は認められなかっ た.すなわち急性胃病変から急性胃潰瘍への進行には酸 分泌の克進, それに伴らペプシン分泌などが大きく関与 することが推測された，これらの深い潰瘍化への進行を 抑えるのに迷切は予防的効果があった。

3), 上部消化管出血にする薬物迷切の効果と限界 :
因 7 ヒスチミン $2 \mathrm{mg} / \mathrm{kg}$ 連続投与と熱傷による胃 潰腸形成 $\times 40$

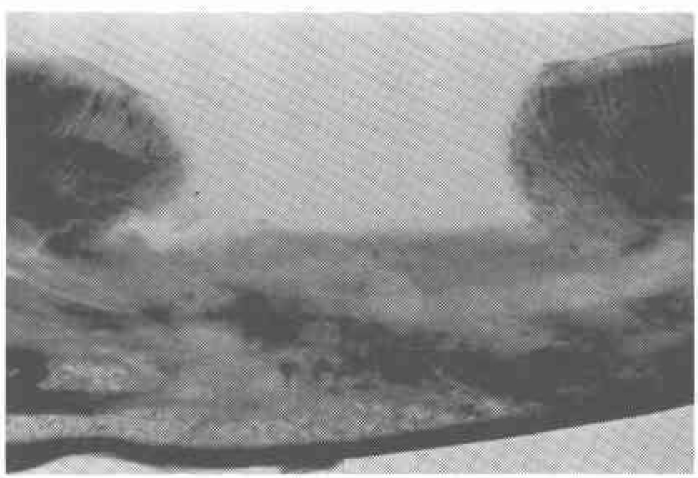

過去15年間に 経験した上部消化管出血例は163例であ った. その内出血早期に保存的治療としていわゆる薬物 迷切を30例に行った. 万法は9), hexamethonium bromide ( $\left.\mathrm{C}_{6}\right) 25 \sim 50 \mathrm{mg}$ と硫酸アトロピン0.5mg を 6 時間每に 筋注し，経口的には冷却した Maalox (制酸剤)を投与 しまた鎮静のため diazepam なども使用した。

それらの内止血し，治癒にむかった著効例は30例中10例 $(33.3 \%)$ ，一時止血後再出欰した有效例は 7 例 $(23.3$ \%)，無効例13例 (43.4\%) であった。これらの内，最 終的に手術を行った症例は16例で53.3\%であった。薬物 迷切の効果之潰瘍の深達度についてみると, 著効例は 病変がびらん〜U1 IIであった15例中 7 例 $(46.7 \%)$ に 対し，U1 III〜UI IVのI5例中 3 例（20\%）であった。す なわち老人で病変が筋層を越え深くまで達したものには 有効でなく，熱傷後に発生した急性胃病変や潰瘍が浅い ものには有効であった（表 リ）.

表 1 薬物迷切の効果之Ul (深達度) (上部消化管 大量出血例)

\begin{tabular}{|c|c|c|c|c|c|c|}
\hline & \multicolumn{2}{|c|}{ 著 効 } & \multicolumn{2}{|c|}{ 有 効 } & \multicolumn{2}{|c|}{ 無 効 } \\
\hline びらん & 4 & \multirow{2}{*}{7} & 0 & \multirow{2}{*}{2} & 5 & \multirow{2}{*}{6} \\
\hline Ul- II & 3 & & 2 & & 1 & \\
\hline Ul- III & 3 & \multirow{2}{*}{3} & 3 & \multirow{2}{*}{5} & 4 & \multirow{2}{*}{7} \\
\hline Ul- IV & 0 & & 2 & & 3 & \\
\hline & & 10 & & 7 & & 13 \\
\hline
\end{tabular}

\section{IV. 考 察}

急性胃病変, 急性胃潰瘍および慢性胃潰瘍の病態と成 因は必ずしも同質のものとは考光にくい点があるが，こ 
れらは一連の病期の差であるのか，もしくは全くの異質 のものであるのか現在でも不明である. Schwarz ${ }^{10)} ら$ の, “no acid no ulcer” といら考兵の時代から, radioimmunoassay の進歩により消化管ホルモン(ガストリン, セクレチン, GIP, VIP，モチリン，ソマトスタチン等） が血中で測定されるに至り，種々の調節機構（胃分泌や 消化管ホルモル等）が明らかになりつつある. しかし今 日でも,これらの胃病変は粘膜伩する defensive factor 之 aggressive factor との力関係で潰瘍が発生するとい ら考えが一般的となっている。そこで慢性胃潰焪発生の 成因を考学る場合, これとの関係が推察される急性胃病 変もしくは急性潰崵をとりあげることも一方法である う. その発生誘因としては, 中枢神経障害から薬剤の作 用などと数え切れない. しかし最近では急速に都市化 し, 複雑化した社会に反映してか急性出血性胃病変, いわゆるストレス潰瘍が増加している. 1935年, Hans Selye $\mathrm{e}^{\mathrm{11})}$ によって最初にストレスといら概念が医学に導 入され，また1936年には general adaptation syndrome (沉適店症候群)の一部分症に, 胃・十二指腸の潰瘍性変 化 ${ }^{12)}$ が発生すると報告されている.1948〜1950年頃より 外傷・手術・傷・感染·疲学・情動緊張などを原因とする ストレスがalarm reaction を生み出し, その歪みが胃・ 十二腸に病的所見として表われるものを一般にストレス 潰瘍 (acute stress ulcer, stressinduced ulcer, stress-associated ulcer）と呼ぶようになった，著者らは，日常よく 遭遇する熱傷後に発生する消化管出血に注目し, stressor として熱傷を選び，実験的に急性胃病変を再現してその 発生過程と対策に関して検討した. Harkins ${ }^{13)}$ らによる 之1823年 Swan は死亡した熱傷患者を剖検し, 胃の病変 を指摘したといら，さらに1842年 ${ }^{1)}$ Curling が熱傷患者 の急性十二指腸潰瘍 6 例を報告して以来, 熱傷に続発す る胃・十二指腸病変を Curling ulcer と呼び, その後, 数多くの報告が見られる. その結果, 臨床像については かなり明確になって来たがその成因に関しては多くの実 験的研究にもかかわらず不明な点が多い. 著者らはこれ まで各種の病的状態下飞批ける消化管の微小循環（微細 血管構築）の変化の研究を行ったが，今回の結果より, 熱傷後早期に批いては粘膜表層上り深層へと波及する微 小㣶環障害が観察され，それ伴って胃病变が進行する ことを明らかにした.この経時的推移を分析してみると 以下のように考光られる。まず熱傷といらストレス負 荷により視床下部を介し，まず交感神経の興巂が起り

(alarm reaction), 胃壁内の細動脈が収縮し，胃粘膜は
虚血状態になる，これに平行して 細静脈の収縮孔起り (集合静脈の抎張と血球の sludging, stasis)，毛細血管 内の血流のうっ膟と途絶, さらに粘膜先端の微小血栓が 発生すると思われる．またこれらの背景に，粘膜下に打 ける多数の動静脈吻合が交感神経刺激などにより作動し たり，平滑筇の㐿縮などが加わり粘膜血流量が著るしく 減少すると思われる。この原因物質としてヒスタミン，

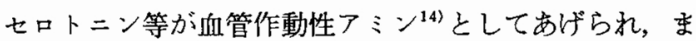
た Friesen ${ }^{15)}$ らはこの循環不全を熱傷時微細血管の透過 性え進により血漿成分が漏出し，血夜の粘調度方進によ るものと報告している，その他敗血症 ${ }^{16)}$, 血液疑固障

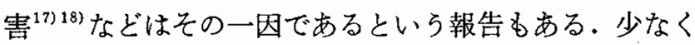
とも熱傷後早期にはこの様な胃壁内，ことに粘膜の微小 循環障害が急性胃病変の素地となっているものと思う． 熱傷後の循環動態の变化を数值的把握するため, われ われは ${ }^{85} \mathrm{Sr}$--microsphere 法を使用した。 その他 Xe ク リアランス法, 熱電対, アミノピリンクリアランス, 水 素クリアランス法と各種の血流測定法 ${ }^{19)}$ があり，それぞ れに一長一短があるが，胃壁内の微細血管構築標本作成 之同一条件で施行出来るという利点のため, ${ }^{85} \mathrm{Sr}$.-microsphere 法を用いた. ラットでは胃全層の血流についての 測定しかできなかったが，熱傷後早期，1〜4時の間は 著明に血流の低下が観察された．しかしこの变化を直に 粘膜内血流量の低下とすることができるかどらかには問 題がある.すなわち，Pruitt ${ }^{20)}$ らの報告の様な熱傷後の hypovolemia, cardiac output の低下，全末梢血管低抗の 増加なども考えなければならない，しかし今回の測定方 法による胃血流は cardiac outputに対する相対的数值で あるので，胃への血流量の低下を論ずるかぎりは問題な いと思われる．したがって著者らが得た胃全層での血流

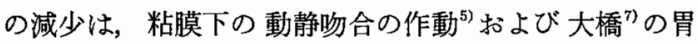
虚血時に扣いてはまず粘膜の血流量が低下するといら事 実より, 主に粘膜の血流量の低下とみて良いと思う。こ の粘膜血流の低下（粘膜虚血）により粘膜抵抗に変化が おこるという考光の下に，著者らは hexosamine の分解 酵素を測定した。一般に glucosaminidase は主にへパラ ン硫酸，ヒアウロン酸に関係をもち，粘液産生に関与 し, galactosaminidase はコンドロイチン硫酸に 関与す るといわれる．熱塲後では胃粘膜の glucosaminidase 活 性の低下が明らかとなり，粘膜産生が低下したり， mucous barrier が破壞されたりして，粘膜低抗が減弱し たものと思われる．この様な粘膜環境の下に，酸やペプ シンがその量・濃度は低くても作用する事により粘膜が 
因8ストレス溳湟発生機序

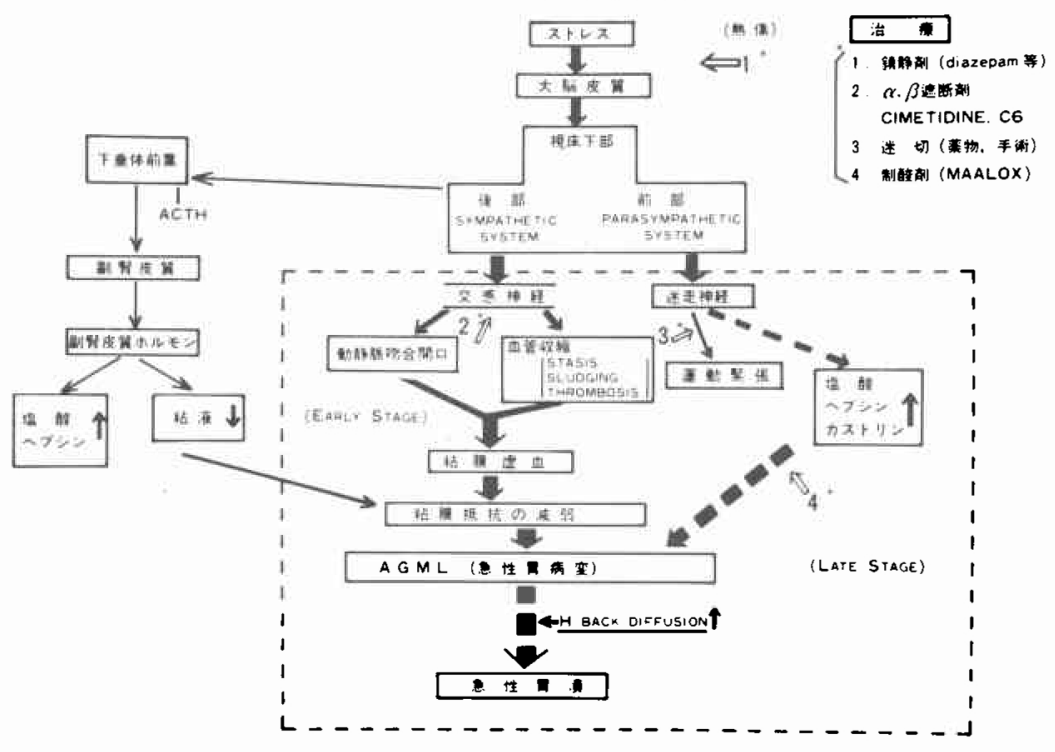

破壊されるものと考えられる．しかし， O'Neill ${ }^{21)}$ の報 告のように熱傷時に和ける胃酸分泌は決して六進してい るとは思われない，実験的には，熱傷単独では粘膜びら ん（出血点）のみにとどをり，72時間後には回復傾向が みられる.一方, ヒスタミン, ガストリン等の酸分泌刺激 剂を投与したり，稀釈塩酸を直接注入すると，深い急性 胃潰瑏となった事実, また迷切処置例に同様な負荷を与 えても潰瘍形成はみられなかったことより，潰瘍化への 因子にはペプシンや酸等の攻撃的要素が必要である事が 判った.ここで当然 Davenport ${ }^{22)}$ の $\mathrm{H}^{+}$逆払散の理論 が引きあいに出されるが，最近（1978年）の William， A. Mersereau ${ }^{23)}$ らの報告では, $\mathrm{H}^{+}$逆拡散の 要素とし て粘膜の損傷があり，しか子粘膜血流の維持があげられ ている、これを言い変えて見ると，たと光粘膜損傷があ っても熱傷早期の様な粘膜虚血状態時には, $\mathrm{H}^{+}$逆拡散 は起こりにくいのであろう.

急性胃病変・急性胃潰㵣の対策については, これらの 悪循環を断ち切る事になる。臨床的には, 緊急胃内視鏡検 查により病変括よび出血状況を把握し治療方針を確立す る.すなわち病変が急性胃病変のようなびらんや浅い潰 瘍の際は, いわゆる「薬物迷切」を主とした保存的療法 を行う、われわれは未だ䠛床的には POB cimetidine は使用していないが今後検討すべきもと思う，潰瘍病 変が樑く，また血管露出例では内視鏡的処置などの保存 的治療を応用することにより，重篤な状況下での緊急手
術を避け救命率を上げる事ができよう（図8）.

\section{䊅 語}

今回臨床的に Carling's ulcer に注目し，また実験的 に急性胃病変を再現した。熱傷後まず, 視床下部一交感 神経系を介した血管性变化, すなわち粘膜下では動静脈 吻合が開き，それにより粘膜面では微小循環が障害され 胃粘膜は著明な虚血性変化をきたす。これを微細血管構 筑と microsphere 法により証明した. 引き続き起る防御 機構の破綻を hexosaminidase の消長により観察した. これまでの早期過程では POB, cimetidine は有效であ った. 熱傷のみでの胃病変は比較的浅いものにとどまる 事が多い，これに副交感神経を介した胃分泌, ペプシン の穴進が加わったり，循環障害で損傷を受けた粘膜から の一部水素イオンの back diffusion 現象が加わりびら んから深い急性潰瘍へと進行して行くものと思われる. 迷切はこれらの深い潰瘍化に対して予防効果があったと いえよう。

（本研究は昭和53年度文部省科学研究費を使用した。）

\section{文献}

1) Curling, T.B.: Onaacute ulceration of the duodenum in cases of burn. Med. chir. Trans., 25: $260,1842$.

2) Walker, H.L. and Mason, A.D.: A standard animal burn. The Journal of Trauma, 8: 1049, 1968.

3）岡 繁樹：胃粘膜の微細。日本脈管学会誌，9: 
19, 1969.

4) 土屋雅春他：微小循環の機能乙調節. 医学のあ ゆみ, $57: 265,1966$.

5）杉山貢：ダンピング症候群における晹管の微 小循環の变動.日消外会誌, $7: 341,1974$.

6) Rudolph, A.M., et al.: The circulation of the fetus in utero. Circ. Res., 21: 163, 1967.

7) 大橋俊文他：胃血流遥断による胃血流分布およ び胃液分泌の変動. 第65回 日消病総会, 口演, 東京, 1979. 4 .

8) 渡辺桂一他：消化管組織内の hexosaminidase 活 性に関する研究．第64回日消病総会，口演，札 幌, 1978. 5 .

9) Gillespie, I.E., et al.: Effect of medical and surgical vagotomy on the augmented histamine test in man. Brit. Med. J., 1: 1557, 1961.

10) Schwarz, K.: Úber penetrierende Magen und Jejunalgeschwür. Beitr. Klin. Chir., 67: 96, 1910.

11) Selye, H.: Thymus and adrenals in the response of the organism to injuries and intoxication. Brit. J. Exper. Path., 17: 234, 1936.

12) Selye, H.: Perforated peptic ulcer during airraids. Lancet, 2: 252, 1943.

13) Harkins, H.N.: Acute ulcer of the duodenum (Curling's ulcer) as complication of burns: relation to sepsis. Surg., 3: 608, 1938.

14) Harjora, P.T.: Gastric ulceration followin ex- perimentally induced hypoxia and hemorrhogicshock: In vivo study of pathogenesis in rabbits. Ann. Surg., 163: 21, 1966.

15) Friesen, S.R.: The genesis of gastroduodenal ulcer following burns., Surg., 28: 123, 1950.

16) Le Gall, J.R.: Acute gastrointestinal lesion related to sever sepsis. Surg. Gynec. \& Obst., 142: $377,1976$.

17) Mcmanus, W.F.: Disseminated intravascular coagucation in burned patients. J. trauma, 13: 416, 1973.

18) Atik, M.: Pletelet dysfunktion: An important factor in massive bleeding from stress ulcer. J. trauma, 12: 834, 1972.

19）土屋周二：腸管の循環とその障害, 日本脈管学 会, 9:37, 1969 .

20) Pruitt, Jr.: Hemodynamic change in the early postoburn patient the influence of fluid administration and of a vasodilation. J. trauma., 11: $36,1971$.

21) O'Neill, J.A.: The influence of thermal burno on gastric acid secretion. Surg., 67: 267, 1970.

22) Davenport, H.W., et al.: Destruction of the gastric mucosal barrier by detergents and urea. Gastroenterology, 54: 175, 1968.

23) William, A., Mersereau, Ph.D., et al.: Inyeractions of gastric blood flow, barrier breaker, and hydrogen ion back diffusion during ulcer formation in the rat. Surgery, 3: 248, 1978. 